\title{
Abaixo a mediocridade
}

\author{
0 vice-presidente do Boston Consulting Group, Michael \\ Silverstein, analisa a recente mudança no comportamento do \\ consumidor de classe média e sua conseqüente migração para \\ as duas extremidades do mercado.
}

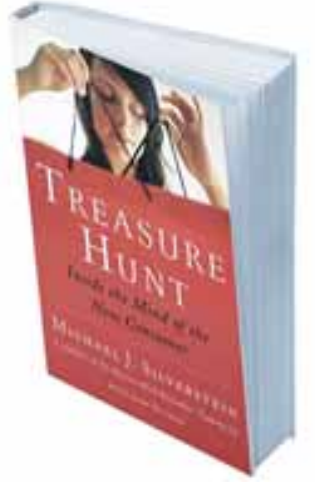

Treasure Hunt - Inside the Mind of the New Consumer Michael Silverstein e John Butman Penguin Group, 2006, 272p.

por Lígia K. Ishida

$\mathbf{A}$ vasta experiência acumulada ao longo dos anos à frente do Boston Consulting Group, acompanhando clientes dos mais diversos segmentos, fez de Michael Silverstein um verdadeiro especialista em comportamento humano. Em seu primeiro livro, o best-seller TradingUp, Silverstein analisou os motivos que levam os consumidores de classe média a adquirir determinados produtos de luxo, até então restritos às camadas mais abastadas. No mais recente, Treasure Hunt, ele dá um passo além e afirma que esses mesmos indivíduos, em uma atitude aparentemente contraditória, estão também migrando para o mercado low end em muitos setores, como varejo, alimentação e hospedagem. Mesclando histórias reais de consumidores e empresas, o livro traz um panorama completo dessa importante e significativa parcela do mercado.

0 autor argumenta que o fácil acesso à informação, impulsionado principalmente pela Internet, transformou a compra em uma atividade bastante complexa. 0 consumidor tornou-se um especialista em compras, capaz de rapidamente comparar e avaliar produtos e serviços. Por essa razão, já não se contenta com uma solução medíocre para os seus problemas. Pelo contrário, vive em uma incessante "caça ao tesouro", buscando o produto ideal pelo exato preço que deseja pagar, seja ele um sabonete ou um automóvel.

A novidade équeas pessoas passaram a economizar nas categorias que consideram menos importantes - ou até mesmo a eliminá-las da lista de compras - para poder destinar mais verba àquelas quelhes despertam maior interesse. 0 mercado, portanto, está sendo bifurcado - enquanto os dois extremos crescem, alta e baixa renda, a porção intermediária, que supostamente deveria suprir as necessidades da classe média, parece rumar à extinção.

Tal fato explicaria o contínuo crescimento das empresas focadas no mercado trade down, como Wal-Mart, as populares dollar stores e os chamados hard discounters, representados por redes desupermercados como a al emã Aldi ou a espanhola Dia, esta última operando no Brasil desde 2001. Todas elas preocupam-se em oferecer ao público alternativas não apenas básicas e baratas, mas principalmente confiáveis, já que o nível de exigência dos compradores atinge patamares cada vez mais elevados. Com isso, a compra deum produto barato 
deixou de carregar consigo uma conotação negativa para se tornar uma espécie de prêmio para os indivíduos mais versados na arte do consumo.

0 preço, no entanto, não éo único fator determinante. Silverstein chama a atenção para a necessidade de se compreender também os aspectos emocionais que, além de motivar as pessoas à compra, também as estimulam a desembolsar uma quantia maior. 0 valor atribuído a determinado produto ou serviço, explica o autor, sempre esteve relacionado a sentimentos como esperança, medo do futuro ou cuidado com a família. O s bens materiais que conseguem entregar ben efícios intangíveis para preencher os vazios emocionais representam a essência do mercado trade up.

Existem ainda al gumas poucas empresas que foram capazes de trabalhar eficientemente os dois extremos do mercado. Um bom exemplo é a rede de hotéis Marriott, que controla tanto o luxuoso Ritz-Carlton quanto o econômico Fairfields Inn. Tal estratégia acompanha muito bem a nova dinâmica da classe média e permite que as organizações atinjam, simultaneamente, os dois pólos de crescimento do mercado.

0 leitor desatento poderia eventualmente se decepcionar com algumas colocações aparentemente óbvias encontradas ao longo do livro. 0 autor sugere, por exemplo, que as empresas escutem o consumidor, sempre buscando aumentar a qualidade e diminuir os custos dos seus produtos. Porém, é importante ressaltar que mesmo essas práticas simples ainda não são adotadas de maneira ideal por um número considerável de empresas, as quais, apesar de acreditarem conhecer profundamente seu consumidor, na realidade não enxergam além dos dados sociodemográficos coletados nas pesqui- sas. Até mesmo gigantes como General Motors ou Kraft Foods correm o risco de ficar presas no mercado intermediário justamente por não terem acompanhado as constantes transformações do público consumidor.

É evidente que a teoria proposta pelo norte-americano Silverstein não pode ser diretamente aplicada à realidade brasileira, sem qualquer adaptação. Primeiramente, o cenário econômico e a própria definição de classe média são completamente diferentes nos dois países, o que obviamente tem impacto direto sobre o consumo. São discutidos também alguns aspectos característicos da cultura norte-americana, como o uso de cupons de desconto na estratégia trade down. Apesar disso, o livro consegue de fato desvendar a mente do consumidor, independentemente da sua localização geográfica, eestimular inúmeras reflexões imprescindíveis para a sobrevivência das empresas no novo mundo bipolar.

\section{Lígia K. Ishida}

Publicitária

E-mail: ligiaishida@gmail.com

\section{0 mercado está sendo bifurcado - enquanto os dois extremos crescem, alta e baixa renda, a porção intermediária, que supostamente deveria suprir as necessidades da classe média, parece rumar à extinção.}

